\section{(1) 素材置場}

品種, 寸法別に適当な大きさの palletに収めるとよい。

(2) blusting

完全な除ジン装置を備える必要がある。

(3) tumbler 装犆

液体が自由に通過でさる孔を有するもので, 酸槽に半 分漫った状態で回転させる。この槽は同時に水洗槽を兼 ねる。鋳物の酸洗イには高価なフッ化水素酸を使らか ら，なるべく廃酸を作らないために, 塩酸との混酸とし て鉄塩の弊害を抑え, drag-outを新酸の charge で補な いながら酸性能の低下を防ぐ。そのために acid storage を別に設ける。

(4) Flux 装置

tumbler から取出した素材は，水で需れたままの状態 で直らに flux 槽に入らないと肌にサビを発生するが, 同時に水を過剩に flux へ持込むと, flux が希釈される からこの間の配虑が必要である。また flux 処理後, 直 ちに素材から余分の液を排除する必要から， conical cylinder を使った。この場合加温された flux 液は腐食 性が強いから 18-8 ステンレスを使うのがよい。

(5) 乾燥装置

flux 液が素材の一隅に滞留していると激しいsprash の原因となるので，素材を反転させながら乾かす必要か ら，回転 cylinder を使い熱風を吹込む。

(6)メッキ装置

第 6 図の自動メッキがのぞましい。この場合，むしろ スキー場のリフトみたいに，ロープを使って考案した方 が容易ではないかと思 5。

(7) 冷却装置

鋼製 conveyor か，傾斜させた screw conveyor で
水から取! H一少。

(8) 搬送装置

素材置場および製品置場は, garter crane が便利で, 前処理工場には mono rail hoistを使5。メッキ関係 は, guide railによって導かれたロープの動きを利用し た自動メッキとする。

またこの場合の白煙処理は, hoist や craneを使わな いから，覀鉛釜の上に直接 hood を取付けることができ るので, pipe の場今に比べれば集煙が楽である。

\section{4.むす ひ}

以上 pipe と継手に対する, 溶融亚鉛メッキの機械化 について記した。要するに素材の形状に応じて，その般 送と取扱いに都合のよい装置を考察することであるが， この際あまり欲ばって多方面の用途を図ると，かえって 中途半ぱなっもとなる。

しかしこのような装置は, 前記の pipe に対する装置 以外には, plant として販売されているものは見当らな い。したがって自ら考察した機構と希望能力を makerに 示して，装置を作らせるほか入手の方法がない。

そのため，既設装固についての詳細は公表される機会 がなく，またそれを第三者が公表することは，諸般の状 勢上適切ではないと思われる。したがって，この程度の 記述に止めざる得なかったことを遺憾に思う。

\section{文献}

- Metal Finishing Journal, July, p. 273 (1960)

- Electroplating and Metal Finishing, August, p. 274 (1958)

- 特竍公報, 昭36-2557

- 特許公報, 昭35-4858

- 特部公報, 昭36-20861

\title{
振動バレル研摩のレイアウトと自動化
}

新東プレーター(株) 武山栄作

\section{1.まえがき}

回転バレル仕上げ法の普及発展は, 振動バレル仕上げ 法の開発を促がした。そして振動バレル仕上げ法がわが 国に導入されて以来, 数年を経ずして仕上げ目的に応じ 各種型式の仕上げ機が製作され，興味ある仕上げ法とし て期待されている。

振動研摩機は, 通常振動数 1500 ３600 c.p.m., 振幅
2〜6 mm の過激な高速振動を 研摩槽に与えるため，機 械的構造, 構成部品の剛性, 加工精度, 材質などを十分 に検討しないと，長時間連続稼動は不可能である。 また仕上げ能率，仕上げ精度，コストの点から，振動バ レル専用のメディア，コンパウンドを使用し，適正な使 用条件の選定は基本的要素として重要である。

その忘用分野は, 各種金属, 合成樹脂, 磁器, 宝石飞 抢よび，時計，カメラ，電気部品の小物部品から，鋳 
第 1 表

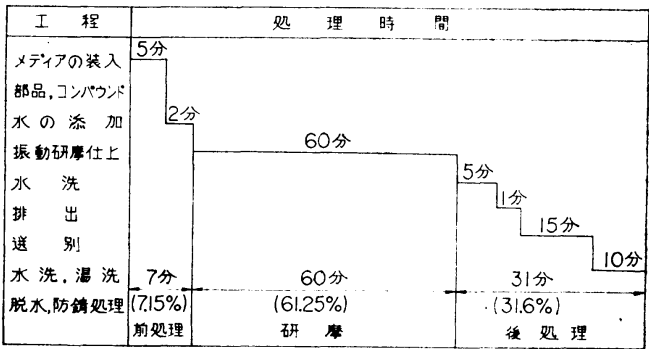

鉄, 鍛造, ダイカスト，の大物部品の表面仕上げ，バフ 仕上げに該当する平滑な光沢仕上げ作業も可能となり, 広範囲の仕上げ法として利用されつつある。

最近これらの仕上げ装置の稼動率をさらに向上さ せ, 前後処理操作による労力の減少, さらに前後工程を 自動ラインに操入させるなど, 自動化への要望が急速に 高まりつつあるため, ここにその自動化についての新し い動向について解説し，参考に供する次第である。

\section{2. 自動化された振動バレル 仕上げ法の応用例}

わが国において，現在自動化された振動バレル仕上げ 装置を使用した応用例は比較的少ないが，利用範用の拡

第 3 表 バッチタイプ原価表

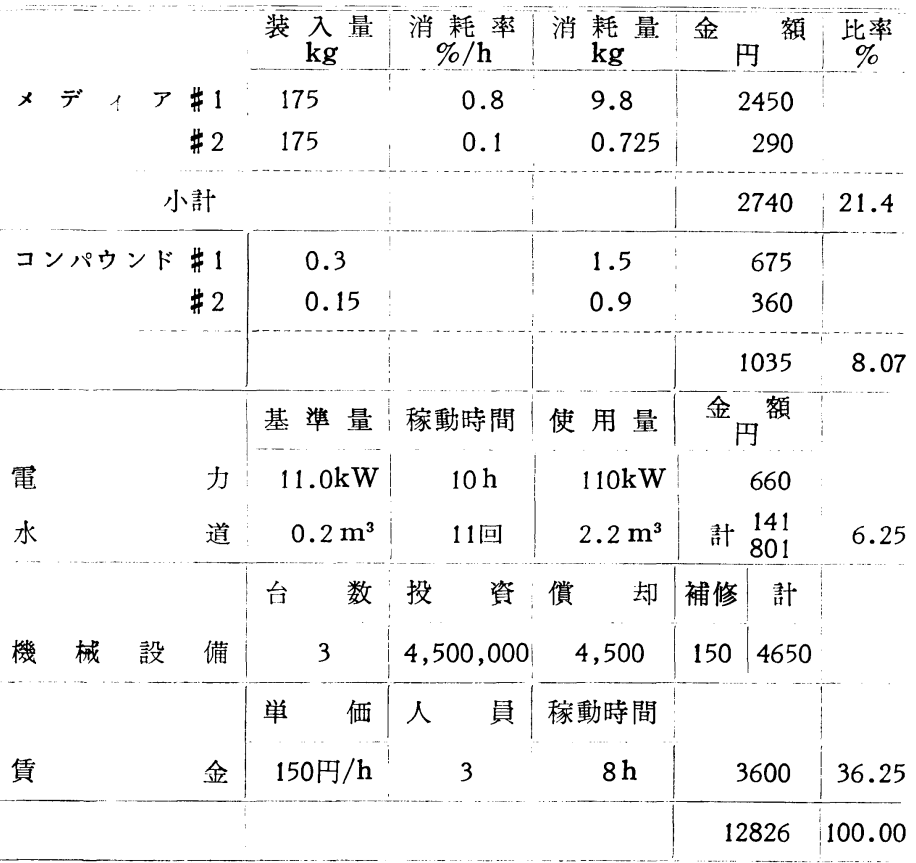

$$
\begin{array}{ll}
\mathrm{A}=\frac{12826 \times 0.322}{500}=8.26 \text { 円 } & \mathrm{C}=\frac{12826 \times 0.168}{400}=5.38 円 \\
\mathrm{~B}=\frac{12826 \times 0.336}{1300}=3.32 \text { 円 } & \mathrm{D}=\frac{12826 \times 0.174}{1800}=1.24 \text { 円 }
\end{array}
$$

第 2 表

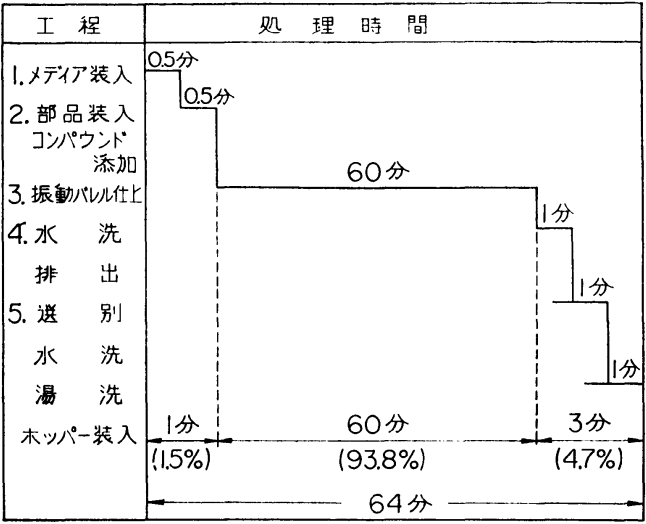

大によって，急速な発展が期待される。欧米においては すでに各機械加工分野で使用されている。

つぎに，その応用例について述べて扣く。自動車の Transmission Valves は切削加工後 $0.2 \sim 0.5 \mathrm{~mm}$ carbo-nitrited し，焼入れ後 $178^{\circ} \mathrm{C}$ で焼モドシされる。 さらに, センターレスグラインダーとラッピングによっ て仕上げられ，許容寸法は $0.007 \mathrm{~mm}$ ，表面アラサ 0.12 $\sim 0.5 \mu$ に仕上げられる。この場合, 両側のシャープ エッジを除去しなければならない。従来は tumbling barrel を使用していた。その作業条件 は, 部品の装入数 300 ケ（径 $1 / 2 " \times$ 長サ $\left.11 / 2{ }^{\prime \prime}\right)$, コンパウンド $450 \mathrm{~g}$, 回転数 14 $\mathrm{rpm}$, 時間 $1 \mathrm{~h}$ 水をフタ一杯まで注入し た。このような条件でも，ときどきキズ を生じ，またマグネットの選別機を使 用した場合には脱磁しなければならない し，キズを生じやすいため手で選別して いた。したがって 300 ケの処理を行なう に $11 / 2 \mathrm{~h}$ を要し、コンパウンドは，1回 毎に排出するため高価となった。

この場合, 容積 $280 l$ の連続式振動バ レル研摩機を使用乙，装入量 $90 \%$ ，振 動数 $2200 \mathrm{cpm}$ で $10 \mathrm{~min}$ 行なった場合 シャープェッジは 0.025〜0.063 mm の 丸味を均一につけることができ，キズを 生ずることはない。この場合, コンパウ ソドは，連続循環式装置を付属してい る。またメディアと部品は, 研摩槽から 連続して排出し，バイブレーターセパレ ーターにてフルイ分けられ, メディアは ベルトコンベアーにより研摩槽に戻る。 メディアは $360 \mathrm{~kg}$ の酸化アルミニウム の塊状メディアを使用するが，比較的耐 
第 4表 自動ライン原価表

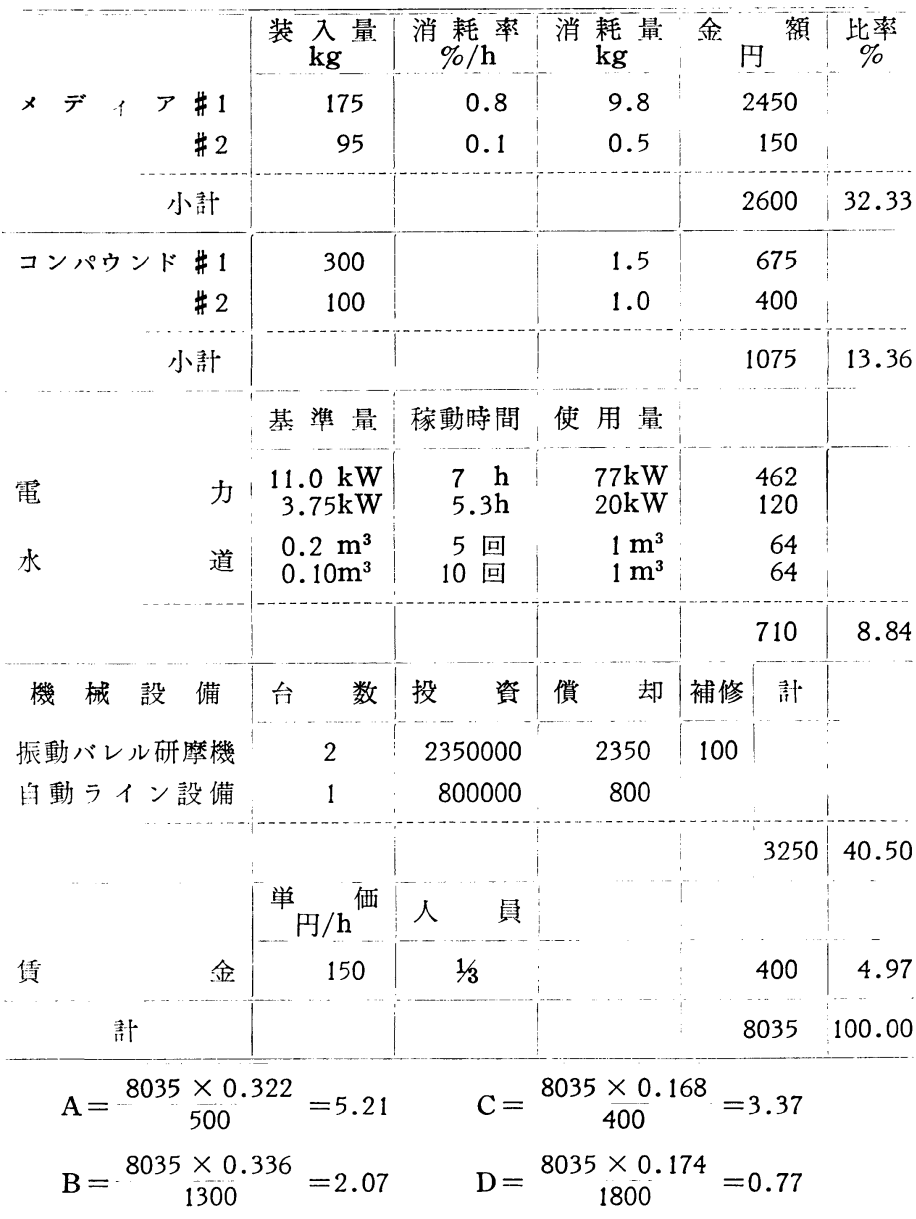

第 5 表 処理部品の作業条件

\begin{tabular}{c|r|r|r|r|r|r|r|r|} 
部品名 & $\begin{array}{c}\text { 見掛容積 } \\
\mathrm{dm}^{3} \text { /回 }\end{array}$ & $\begin{array}{c}\text { 生産量 } \\
\text { 個/日 }\end{array}$ & $\begin{array}{c}\text { 処理容積 } \\
\mathrm{dm}^{3}\end{array}$ & \multicolumn{2}{|c|}{ 仕 上時 間 $\mathrm{h}$} & \multicolumn{2}{|c|}{ 処 理 回 数 } \\
\hline $\mathrm{A}$ & 0.2 & 500 & 100 & 2.0 & 0.7 & 2 回 & 2 回 \\
$\mathrm{B}$ & 0.08 & 1300 & 104 & 1.0 & 0.5 & 2 回 & 2 回 \\
$\mathrm{C}$ & 0.13 & 400 & 52 & 1.0 & 0.5 & 1 回 & 1 回 \\
$\mathrm{D}$ & 0.03 & 1800 & 54 & & 0.7 & & 1 粗仕上 & 仕 上 \\
\hline
\end{tabular}

第 6 表 振動バレルの処理能力

\begin{tabular}{|c|c|c|c|c|c|c|}
\hline \multicolumn{4}{|c|}{ No. 1} & \multicolumn{3}{|c|}{ No. 2} \\
\hline 内 & 容 & 積 & $240 l$ & 内 & 容 & $130 l$ \\
\hline (混ディ & 合: & 啙) & $3: 1$ & (混 & 合:部品) & $3: 1$ \\
\hline 装 & 入 & 量 & $85 \%$ & 装 & 量 & $85 \%$ \\
\hline \multicolumn{4}{|c|}{$240 \times 0.85 \times 1 / 4=51 l$} & \multicolumn{3}{|c|}{$130 \times 0.85 \times 1 / 4=27.6 l$} \\
\hline
\end{tabular}

摩耗量が大なるため 1 ケ月に $226 \mathrm{~kg}$ 添 加する。コンパウンドは最初 $2.26 \mathrm{~kg}$ 添 加するが， 1 週間に $2.26 \mathrm{~kg}$ 添加するだ けでよい。この場合, 水は $200 l$ とする。 このようにして連続式振動バレル装置を 採用することにより，仕上げ能率は 3.5 倍,メディア, コンパウンドの経費を $1 / 3$ に減少させた。この仕上げ法の最大の特 徵は, 加工部品は固定治具を使用せず, 常時バラの状態で仕上げられるため, 形 状, 寸法はある程度融通性を持ら, 小種 多量生産部品に限定されることなく, 加 下部品を整理することにより，メディ ア, コンパウンドを取換える必要もなく 連続作業が可能である。

\section{3. 原価構成から見た 自動化の必要性}

バレル仕上げ法の作業特質として，仕 ト:げ作業は自動的に行なわれるが，その 前後処理工程に大量のメディアの出入 れ, 洗浄, 製品との選別など労力を必要 とし, その処理作業は繁雑で長時間を要 する。また水を使用する関係上，作業環 境はかならずしも良好とはいい難い。い まバッチタイプの振動研摩機を使用した 場合の,一般的な処理時間を第 1 表に示 †。

この表から，振動研摩の仕上げ時間を 60 分とした場合, 前処理工程に $7.15 \%$, 後処理工程に $31.6 \%$, 実稼動は $61.25 \%$ にすぎない。処理時間が短縮されれば稼 動時間はさらに低下寸るため, 作業人員 を増加しなければならなくなる。これに 対し，自動ライン方式を採用した場合を 第 2 表に示す。この表より, 前後処理時 間は極度に短縮され，稼動率を $93.8 \%$ に向上させることができるため，一定の 生産量を処理する場合, 研摩機の使用台数を減少させ, またボタン操作により稼動されるため, 作業人員を削減 できる。

つぎに, 一定部品を処理する場合, バッチタイプの作 業方式と自動ライン方式を採用した場合の, 生産コスト の比較対照を第 3 表, 第 4 表に示す。第 5 表, 第 6 表は 処理部品の作業条件を示したものである。

上記の表より, 生産コストは $62.8 \%$ 減少し, 月額に して 120,000 円のコストダウンを可能ならしめる。以上 


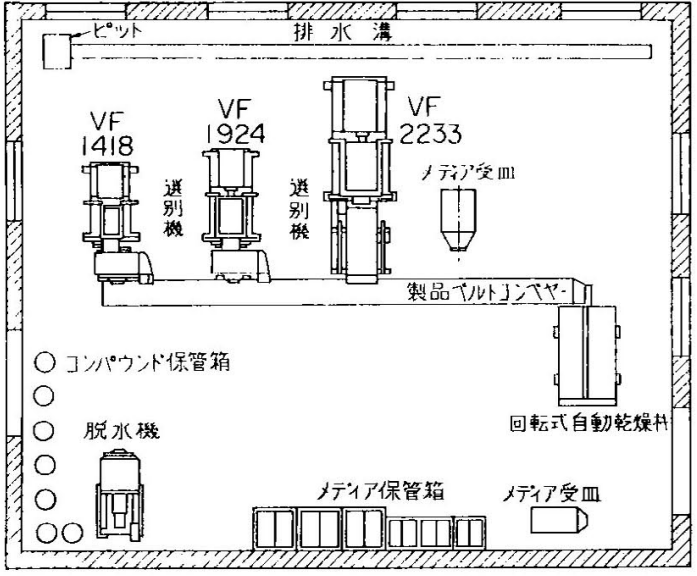

第 1 図バッチタイプのレイアウト

のことから，振動研摩仕上げ装置の要点は，前後処理作 栄の用辞化によって達成できるものである。

\section{4.レイアウト}

振動仾摩作業は,メディア，製品の洗海をひんぱんに

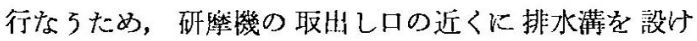
る。流出するメディアのスラッジにより，排水口が塞が れることがあるため，ピットを設け沈䟝させて排出せし

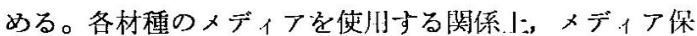
管箱は比較的広い設置面榬を必要とし，肌入入容易 な取出し口を設ける。第 1 图は, $80 l, 130 l, 240 l$ の 各種振動研摩機を設置した半自動式のレィアウトの一例 て，選別機を配置し選別されたメディアは，搬选箱に入 りホイストにより研摩槽にもどる。この場合，バケット ローダーでもよい。製品はベルトュンベアーにより水洗 イされ，乾燥機に入る。小物部品は脱水機により乾燥さ れる。必要に応じ防錆油を粱布する。第 2 図は，240lの 振動研摩機 3 台を設俑した場令を示し, 選别水洗个は才 ンレィティングコンヘアー, メデ（フの投入はハケット エレベーター洗浄, 晖燥は, ベルトコンベアーによって 行なわれる自動ラインの一例を示したわのである。

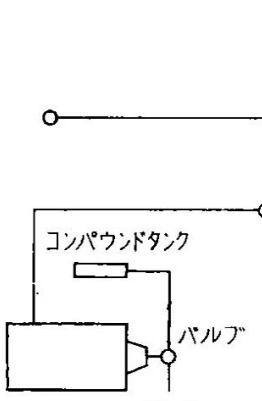

ドレイン

\section{洗济水}

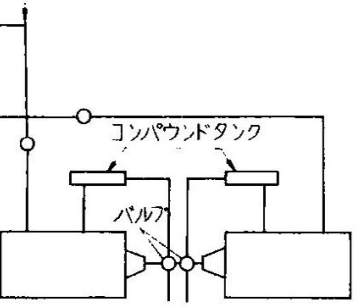

ベレイン

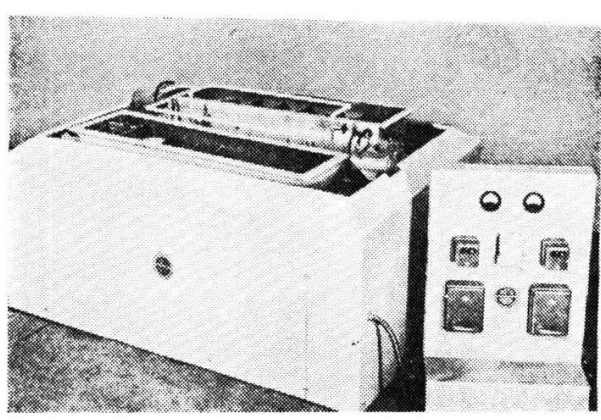

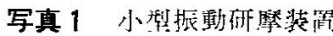

\section{5．小型自動研摩装置}

小物部品を対象とする振動研摩機は，処理容積が小さ いため，傾斜型採用する場合加多い。しかし多量部品 で処理時間が短かい場合飞は，前後処理の白動化が必䒚 である。写真 1 は，小物部品を対象とした小型の振動バ レル研摩機で，研摩槽は二槽から成り，粗仕上げ槽から 什トゲ槽への移吵は，ベルトコンベアーによって運動さ せている。コンパウンドは逨続衙環式で，自動選别機を 採拆しているかどうかは不明である。

\section{6. 自動ライン型振動研糜装置}

振肪砸摩機と摆別機, メディア装入装置をコンベアー で速結させ，一速の自動ラインを棈成させる。この場命 の基本的要素として，傾斜方式では排出量をコントロー ルすることは湘難で，一度に排出されるため、コンべア 一から溢出して落下し，また代上げ部品は打コン变形を 生ずる危険をともなう。また㖄摩槽にフタを取仙けて作 涤する場合，その着脱操作は繁雑である。また密閉した 場合, 摩擦熱と所力が蓄積され，ゴムライニングの寿命 を短縮させる。このよらな欠点を除去するため, 側壁か ら排出するェンドジスチャージ方式で開放型の研摩槽が 好都合である。その例を第3図に示す。これらの自動 ラインタイブは，下記の装圆によって椣成されている。

(1) 固定されたオンレイテ!ングフ：ダーは，長サ

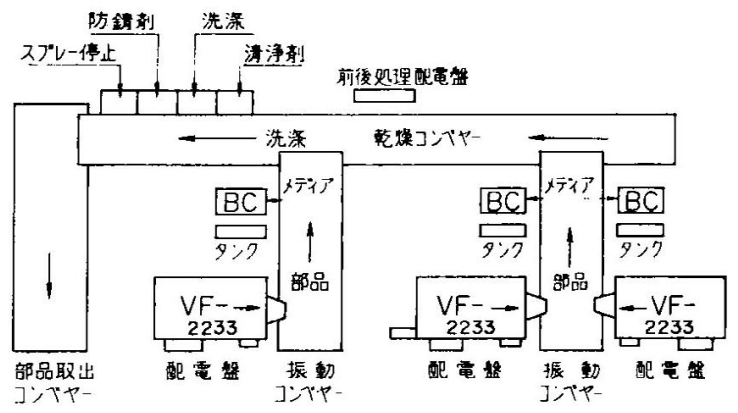

第2図振動研摩萿路レイアウ卜 


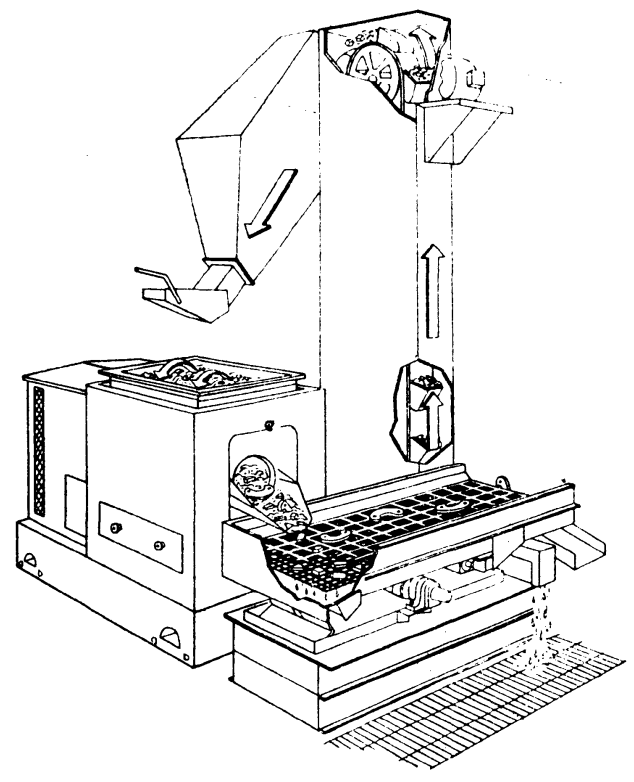

第3図 自動ライン型振動研摩装置

$1500 \mathrm{~mm}$ で, 研摩槽のエンドジスチャージに対し 直角に取付けられ，排出されたメディアと部品を受 ける。

（2）コンベアーは，メディアが通過できる開放型金鋼 板からなり，部品は排出個所认運搬される。2 段目 の金鋼板は正しいサイズのメディアを取出し，水と 小さくなったメディアを通過させ，正しいサイズの メディアは，排出個所でバケットェレベーターに乗 せられる。第 3 段目は，水と細かくなった微粉を排 出する。この場合二つの金鋼板は要求されるサイズ に合わせて取付ける。

（3）バケットエレベーターの搬送能力は1バッチ 90 秒である。

(4) エレペーターの上端部の排出点に, 貯蔵ホッパー を取付けメディアの全チャージ量を眝蔵する。ホ ッパーの下端部には, 排出装置が取付けられ, ダン パーバルブを開けば,メディアは研摩槽に 落下す る。

(5) 研摩槽とオシレーティングフイダーには, スプレ 一ノズルが多数取付けられ, 自動的にコントロール することができる。

上記の各操作をタイマーに連動させることによって， 自動的に操作することも可能である。

第 4 図，エンドジスチャージにより排出せられたメデ イアと部品は，オシレィティングコンベアーによって選 別されメディアはスキップホイストに連続して装入さ れ，一杯になった場合，上部のストレイジホッパーに排

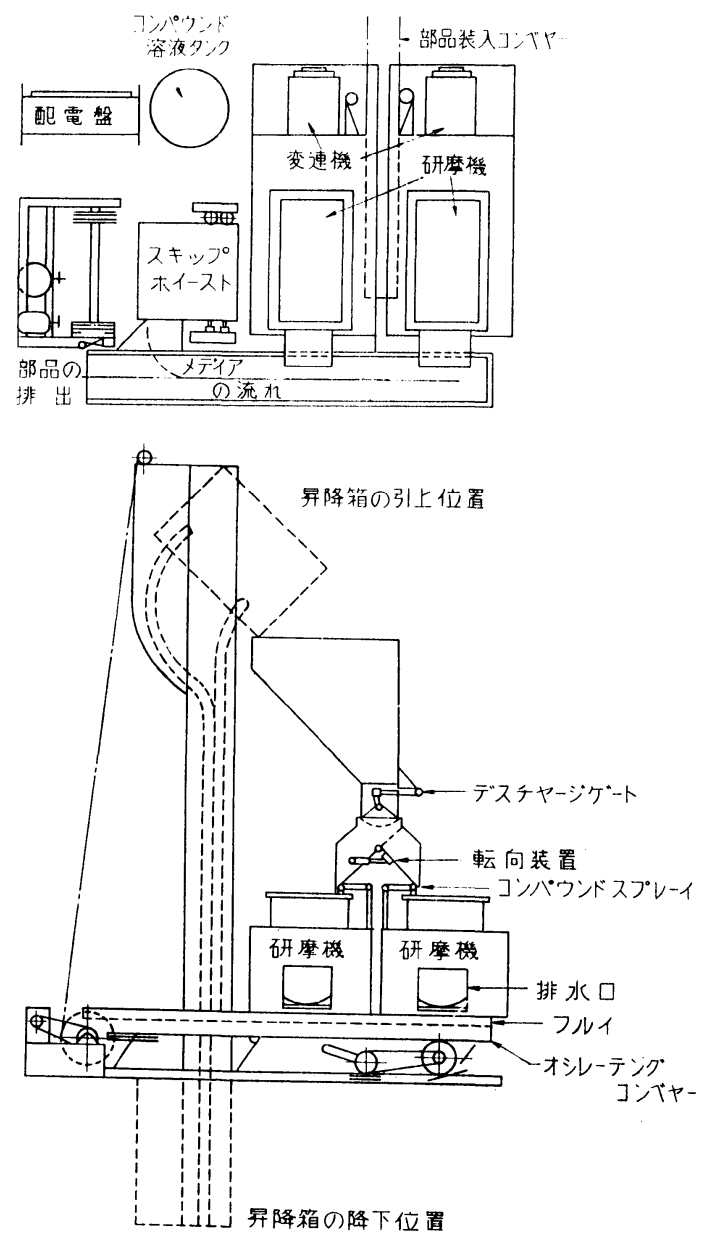

第 4 図自動ラインの一例

出される。ホッパーのゲートはェア操作で開かれ，自動 的に研摩槽の中に落下する。新しい部品はコンペアーに よって装入せられ，仕上げられた部品は連続的に乾燥す るとか, 洗浄乾燥機に連絡するとか, 次工程の容器に装 入される。

\section{7. 連続式振動研摩装置}

多量生産部品を連続的に処理するため，第 5 図に示す よ5な連続式振動研摩機が開発された。この振動研摩装 置 (Lorco Matic Model 144-22) は，一方の側から入 り連続して仕上げられ，規定された時間で一方の側から 排出される。排出した部品は，メディアから自動的に選 別され，次工程に送られる。メディアも洗浄，選別さ れ，ふたたび研摩装置にもどる。この装置は, ニーザー の生産に適するよ5に設計され，自動化を企てることが できる。 

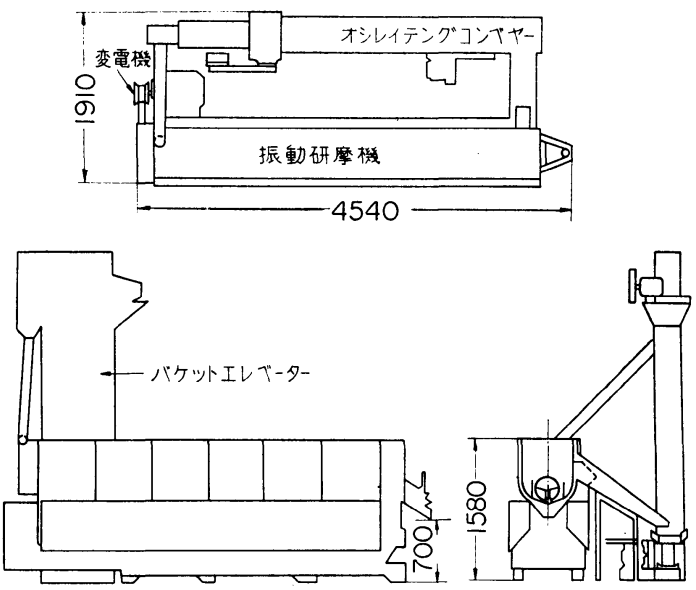

第 5 図連続式振動研摩装置

メディアと部品は，第 6 図に示すように振動と同時に ラセン状の運動をして，投入口から排出口へ連続的に進 行する。この場合, この進行速度を調節するのに三つの 方式がある。

（1）振動数の増减によるサイクルを変える方式

(2) 研摩槽を傾斜させてサイクルを変える方式

(3) Feeding Force 誘導してサイクルを変える方式 またこのような型式は, 大型装置のみを対象とするの ではなく， $200 l$ 程度の中型機にも採用可能である。

振幅, 振動数, 時間は単独に調節可能である。コンパ ウンドは一定比率で添加せられ, 循環装置を付属してい る。これらの操作は, 制御盤の押ボタンにより操作する ことができる。

\section{8. コンパウンドの循環装置}

コンパウンドの循環装置の構成を第 7 図に示す。

(1) 鉄製のタンクは研摩機から排出される細かい微粉 とスラッジを沈殿させる貯蓄タンクである。

(2) 上澄のコンパウンド溶液を研摩槽に注入するに は,ポンプによって吸入する。

（3）排水筒のストレーナーには排水管を接続し，コン パウンド溶液は自然流出により排出される。

(4) 研摩槽に注入する洗浄水は直接排出される。眝蔵 タンクに一定量のスラッジが蓄積された場合には, 自動洗浄装置が取付けられ，自動的に洗浄される。

(5) 新しいコンパウンドは, 規定量を自動的に添加さ れ，正常な濃度によって循環する。

この循環装置は必要に応じ，2 種またはそれ以上の種 類のコンパウンドを，バルブを取換えることによって添 加することができる。以上の操作はソレノイドバルブ,
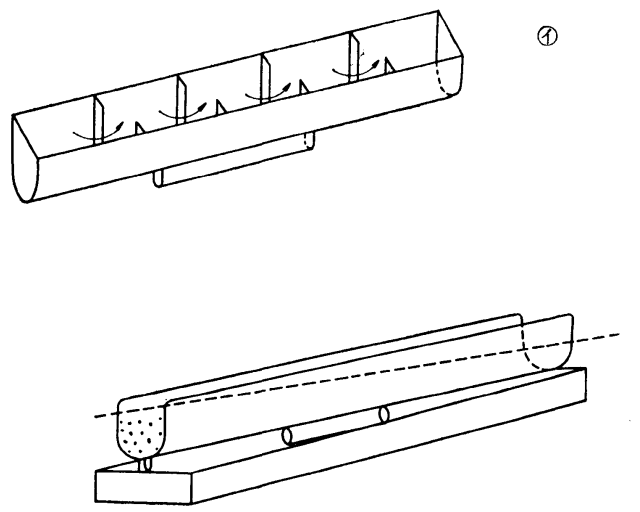

()

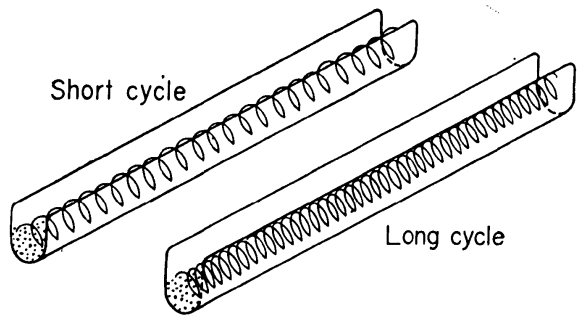

○

(1) 振動数の增減によりサイクルを変える方式

(口) 研摩槽を傾斜させてサイクルを変える方式

(2) Feeding Force を誘導してサイクルを变える方式

第 6 図 連続式振動研摩機の型式

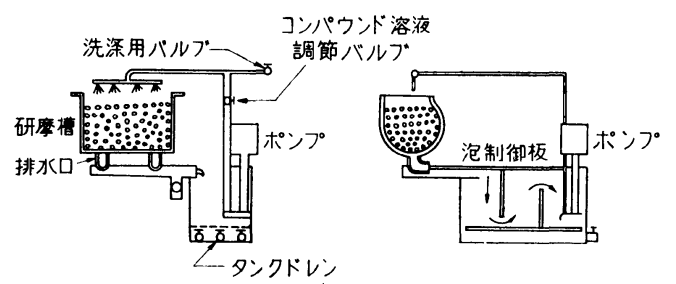

第7図コンパウンド循環装置

タイマーに連絡され, 自動的に行なうことも可能である。

\section{9.むす び}

回転バレルでは，作業時間が普通 2 10 時間の長時間 のため, 前後処理作業 (部品の出乙入れ, 洗浄, 選別, コンパウンド，水の添加）は人為的に行なっていたが, 回転バレルの 5〜10 台分の仕上げ能率を発揮する振動研 摩機では，前後処理作業を短時間に行なわないと稼動率 は低下し，多くの労力を必要とし，その効果は低下す る。この意味から, 最近自動化された新機種について解 説を行なったが，この種仕上げ法は，加工技術の盲点と されていたが，振動研摩装置の自動化によって合理化さ れることを期待するものである。 